\title{
THE PROBLEMATIC FIELDS, THE SCIENTIFIC AND \\ APPLICATIVE TOPICS IN SPECIAL EDUCATION IN COMPLIANCE WITH NATIONAL AND EUROPEAN POLICIES AND STRATEGIES REGARDING DISABILITIES (II) Verginia CRETU*
}

Abstract:

In the second part of article the identified problematic fields, the scientific and applicative topics in Special Education in compliance with national and European policies and strategies regarding disabilities are: positive approach in education that require to focus on the evolving capacities, gifts, abilities and competencies of the child; conditions of real inclusion in teaching -learning process; the support for children with severe and profound handicap through augmentative and alternative communication; psychopedagogy of Individualized Education Program" (IEP); multidisciplinary research programs on assistive and access technology, early education, vocational education and support for employment. The article analyse too the dynamic of paradigms and theories in Special education

Key words: positive approach to disability, Co-operative teaching, cooperative learning, personalised education, Individualized Education Program, Individualized vocational profile, empowerment, augmentative and alternative communication, structural cognitive modifiability, instrumental enrichment

\section{Researches aimed to positive approach in teaching - learning process}

The entire development of social policy based on human rights principles and also the research in the field of special education show potential for the development and the affirmation of the disabled person, even at the level of excellence in a particular field, despite the existence of impairment / deficiencies, but on one condition: to receive differentiated support required on educational and therapeutic activity as well as in vocational education and social and professional integration. Positive approach is a principle that calls on all levels: inclusion of the disabled person in the great individual diversity, valuing the positive aspects and the skills that a person with disability / impaiment can develop, knowledge and action not only in the area of disability that a person has in the sensory, physical or mental plan but especially in the

* Verginia CRETU is a university professor PhD at Faculty of Psychology and Educational Sciences, University of Bucharest. E-mail: cretuverginia@yahoo.fr 
area of disadvantages due to the physical environment, social plan or attitudes and the necessary support for their removal, policies based on recognition and promotion of capacities, abilities and competencies of children and adults with handicap. Positive approach in education require: respect for the evolving capacities of children with disabilities; to focus firmly on the capacities, gifts, talents and capacities of the person as opposed to perceived deficits; set realistic and measurable goals; discover the assets and develop strengths of each child; new forms of assessment, feedback and evaluation; providing an alternative to the undesired behavior or to one activity available in the little measure owing to impairment- it should be an altemative that is readily available to the person; the balance between positive self-image and realistic goals; to reveal the potential assets and develop the strengths of each child. Some publication are dedicated to Positive Approaches and publish studies regarding Positive Approaches practices and tools, book reviews, interviews, policy Positive, Positive Approaches continuum of supports, case studies. Some of the constructs recently developed in psychology appear to be especially useful for researches in light of positive approach. These include positive self-esteem, self-efficacy, self-determination, resilience, optimism, hope, meaning making. Schools are required to conduct functional assessment and to meet special educational needs for pupils who are identified as disabled and are at risk for expulsion. The teacher judgment about students' ability to leam may limit their achievement or increase the learning capacity when the trust in evolving capacities is accompanied with positive support. Effective individualized support measures are provided and proposed by research in environments that maximize academic and social development, consistent with the goal of full inclusion.

\section{Researches on real inclusion in teaching -learning process}

Important studies aim to highlight the conditions which ensure, through the teaching-learning-assessing process, a real inclusion of children with handicap and their progress towards maximum development of their capacities and abilities, especially in the fields and activities they are able to perform, despite their deficiencies. The studies emphasize teaching strategies and theories, in order to give all pupils/students a foundation for designing an effective learning experience. The lot of articles describes cooperative teaching and outlines various arrangements through which it might be implemented. Cooperative teaching is a model, in which general and special educators work in a systematic and coordinated way, in educationally integrated environment. Rink (2002) states that teachers in inclusive environment must provide the following for their students: developmentally appropriate content, clear instructions for practice, opportunities to practice at an appropriate level of difficulty, 
opportunities to participate in appropriately designed task progressions and accurate feedback and assessment of subject matter and role performance. Among research subjects often tackled, the following can be included: designing learning environment based on the diagnostic/ identification of assistance needs; individualized education - to provide learning experiences tailored to each student's interests and learming styles and to imply studentdirected and self-managed learning; individualized modules for students requiring special needs education; training and assistance methods for active learning; the application of cognitive map during the inclusive lesson; open, student-centred educational forms; psycho-pedagogical criteria for the application and development of new classroom materials, adapted to the diversity of individuals; new forms of feedback and assessment. Research tendencies also reflect the concern for preventing the discrimination of children integrated in mainstream schools. Many studies are oriented towards: the creation of an undiscriminating learning environment; an environment which actively engages all students; heterogeneous grouping; inclusive non-formal education; cooperative and collaborative learning in mainstream schools; collaborative problem-solving; maintaining a "problem-solving" environment within which students would develop their own knowledge, while doing teamwork with several classmates and being guided by their tutor. Different models of individualized cognitive training of pupils with leaming disabilities demonstrate permanent results in a short period of time. Children are able to work at their own pace and the nature of the program produces self-motivation. The competition for the child consists of the race for exceeding the goal accomplished in the last session. Confidence grows as each session brings a measure of success. Cognitive training is beneficial for any student; but, the results are especially dramatic for children who have a learning disability.

The integration of children with severe and profound handicap into special education system, special schools and into mainstream schools, has determined a considerable increase in studies focused on this target group. Some of the issues in this educational research field are : how augmentative and alternative (AAC) communication is used by teachers and individuals to compensate for severe speech-language impairments in the expression or comprehension of spoken or written language; the assessment of user's motor abilities, communication skills and needs, how cognition and vision are assessed in order to determine the most appropriate match to a communication system; low Tech methods of Augmentative Communication. Researchers hypothesize that using an AAC device, such as Picture Exchange Communication System (PECS), reveals an increase in nonverbal communication and also in speech, often during later phases, while one noted little or no effect. 


\section{Personalised education. Individualized Education Program}

Descriptions and definitions of personalising education have emerged at national and international levels. The rationale for personalised learning is to raise standards by focusing teaching and learning on the aptitudes and interests of pupils. Personalised leaming is the way in which our best schools tailor education to ensure that every pupil achieves the highest standard possible (OECD 2006). Personalised education involves: highly structured approach that places the needs, interests and learning styles of pupils students at the centre (Learners are central); engaged leamers who are informed and empowered through possibility of choice; assessment that is related to meaningful tasks and includes too assessment for and from pupils/students; a focus on improving student outcomes for all and a commitment to reduce the achievement gap. In Special education, personalization is often synonymous of Individualization, because is clear that some children with different impairments cannot achieve the same leaming objectives (establish for all learners), but is important to valorize the all potential of the learner, in order to develop all his abilities, aptitudes, capabilities and competences (also emotional ones). Evidence indicates that students are more successful in school and are more engaged if they are taught in ways that are responsive to their readiness levels - refers to a student's knowledge, understanding, and skill related to a particular sequence of learning.(Vygotsky), their interests (Csikszentmihalyi, 1990), and their learning profiles (Stemberg et al., 1998). According to Tomlinson (2001, 2003), in adopting differentiated instruction, teachers try to address these three characteristics for each student. In the field of special education the individualized educational intervention has become a tool for planning teacher's intervention for satisfy the unique needs of human individuality, of a particular child / student, for ensuring progress in certain areas of development. Different terms are used: „Individualized Education Program" (IEP) in the United States, in Canada and the United Kingdom, "Projet éducatif individualisé" (PEI) "Projet individuel d'intégration" (PII), in France, Förder Plan in Germany and Switzerland, and Proiect de interventie personalizat (PIP) in Romania. Beyond the name and structure there is a consensus among researchers of the PIP on its elaboration. The adjective Individualized means focusing on a specific individual with its own requirements, choices, aspirations and expectations. Whatever the methods chosen, individualized educational project should be based on multidisciplinary assessment to be conducted jointly by teachers, family and professional staff in support services (Speech therapy, Physiotherapy etc.). PIP should plan the collaboration between all those involved, who must propose realistic expectations from the child, in order to prevent failure. Any PIP should state its goals, objectives, resources, strategies and methods, timelines and responsibilities. The problems that have to undergo extensive research are: focus of the PIP on the forces, strengths and skills that can be 
develop maximum to a child / student/adult; multidisciplinary assessment focused on developing skills and multiple intelligences theory; avoid frustrating situations which can lead the subject to behavioural problems, through the knowledge and consideration of child's limits; developing PIP within initial evaluation of cognitive / academic and functional performance levels, reporting the educational, social psychological evaluation of the child; measurable objectives: annual assessment of progress on annual goals; key adaptive abilities/competencies assessment methodology; development of new scales having regard to response to intervention education; parents- partners in developing PIP, reporting to parents the monitored progress; the PIP project for teenager's life; teacher's training for personalized intervention; personalising experiences from the perspective of parents, educators, advocacy services. Some research directions outlined generate questions like that: are we talking about a global project or about multiple projects? Some of the researchers advocate for a holistic approach, the recovery / rehabilitation, socialization, care and education plan, but in current practice arise some problems. Important researches underline necessity of planning the future of today child and the support needed in various aspects of her life and her social and future professional integration. Person Centered Planning (PCP) is a process that clearly places the person with a disability at the centre of all decision-making in relation to their life. Apart from keeping the person central to and, indeed, leading the process, the fundamental approach adopted when engaging in PCP is to focus firmly on the gifts, talents and capacities of the person as opposed to perceived deficits. Because each person is unique, each Person Centered Planning process is also unique and the structure is underscored by flexibility, informality and creativity. The outcomes of PCP must result in real, positive changes for the person.

\section{Assistive and access technology}

Assistive and access technology provides access to equal opportunities for disabled people to the physical, informational and communicational environment. The concept of assistive technology refer to various equipment, facilities and technologies designed to assist people with disabilities in daily activities to ensure their access to informational and physical environment. Assistive technology programs are found in the accessibility of schools with ramps for persons in wheelchair, tactile carpets that facilitates spatial orientation of the blind, etc. The term "access technology" refers to the hardware and software access technology that a person with a disability (namely with visual impairments) can use, i.e. information technology/computer with everything related to, it including the Internet and services communication related. Multidisciplinary research programs have been stimulated by the European

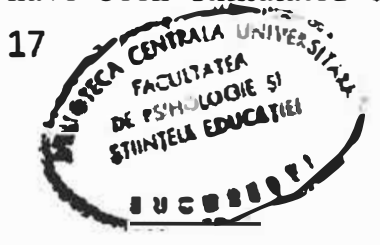


Union focused on providing / implementing the principle of normalization and social inclusion (e.g. "Action Plan" e-Europe 2005 "- an information society for all"). "Access technologies" were created and implemented in the educational process, such as screen readers, speech synthesizers, screen magnifiers, voice input software operating in conjunction with graphics programs on the screen (graphical desktop browsers), scanner + OCR, software to convert Braille music scores, Braille conversion software, games, virtual meetings.

Comparative studies have disseminated new technologies and inclusive practices. Romania is present through: ECDL Foundation Romania - European Computer Driving license for the blind; the designation of part of the botanical garden for the blind people (in Iasi); NGO "Cartea Calatoare" - for the initiation of access technologies, computers and IT, foreign languages courses (Spanish, English and French) and chess - for blind persons in Romania. The conclusion of research in the field of Communication and informational Technology, underlying the psycho-pedagogical problems of e- learning, of accessibility for pupils with various impairments are published in the important reviews: Ejournal of Journal of Special Education Technology; E-Accesibility -National Royal Institute for Blind; British Journal of Educational Technology; Joumal for Visual Impairment \& Blindness; Vision Technology for the Totally Blind. NGO like Society for Information and Teacher Education - SITE); RoChi Romanian Computer Human Interaction and research center (e.g. Center for Study of Disability, University of Leeds) develop applied reserch and actionresearch important for educational practice. The main areas of concern are: consideration of the needs and requirements of children and adults with disabilities in promoting assistive and access technology; accessibility of Web pages; Psycho-pedagogy of e-accessibility and of e-leaming, The Art and Science of Teaching Orientation and Mobility to persons with Visual impairments, models for learning environments supported by computer technology; building professional colleagues communities through ICT, webbased - courses offered by teachers and educators as a way to develop and / or improve their skills of analysis and decision making in educational settings; up e-network of colleagues from different universities; the relationship between individual differences (cognitive, physical, related to lifestyle, etc.); characteristics that determine the effectiveness of educational programs based on new technologies; virtualization, relocation, dematerialisation of shares of knowledge in education; teacher-creator of e-personalised educational products (relative to the precise needs of students dealing with a certain period of time, caused by age, intellect, learning rate, type and severity of language disorder, etc.). 


\section{Early Education}

Early education is very important for the recovering and future social and educational integration of a disabled person. The main concerns in this regard are: children with disabilities early educational intervention; principles of early intervention; importance of early education for children's mental development and the need to integrate the special education programs; support for "maternal school" - parental counselling for 0-3 years children; early intervention in the education of blind children; early intervention in the education of children with mental disabilities; sensory stimulation for the child 0-1 years through a therapeutic method of mobility in the water; positive Behaviour Support in Autism Spectrum Disorders;processes and Outcomes in Family-Centred Services for Children With a Disability; transition to Preschool Special Education; preparation for school integration. A review of the scientific literature on early education was published in Early Education and Development.

\section{Researches regarding vocational education and access to the free labour market of disabled people}

The projects regarding disability issues are directed to: identification of conditions and services needed to improve access to the labor market for people with disabilities; employment stimulation; correlation of the professional background of disabled persons with the requirements of the free labor market; measures for preventing unemployment; developing of new alternatives such counseling centers for disabled persons of County Agency for Employmen/AJOFM (in Romania); parmership between different institutions, NGOs, families of disabled persons and another stakeholders; empowerment disabled people (in accordance with the well known maxim of the disability movement :'Nothing about us without us') to play an active part in their development and to build a skilled workforce in Europe. The research projects in educational field approach especially: correlation of the professional training and background of disabled persons with the requirements of the free labor market; increasing and diversifying the vocational skills; vocational and career counseling; guidance, counselling and information services relating to any aspect of lifelong learning; developing the ability and self-confidence of people seeking work in order to enable them to make a decision on their own career; identifying successful examples / best practices regarding the integration in labor of graduates with disabilities (from pre-university system of national education); types of support for job search and professional integration- the promotion of mediation services on the labor market for disabled persons, assisted employment. Some researches propose new solutions for vocational 
assessment /evaluation: It was understood that the employer is not motivated to engage, since not appear in evaluation documents: skills, abilities, competencies of disabled person for job vacancies: New type of assessment /evaluation require to elaborate Individualised professional profile and to establish the correlation with occupational profiles of job vacancies. Professional profile is a synthetic description of a person, of her skills, abilities, capabilities, competencies, strengths, asset and interests that will allow it to have an occupation / profession and to perform at a certain level.

\section{The dynamic of paradigms and theories in Special education}

A long period of time in all the field of special education, the researches were reported to theories and paradigms that have had the goal to reveal the specific features of different deficiencies/ impairments. These preoccupations led to a better understanding of the features of handicapped children and also on his particular way of development and also to implication towards the training programs in schools. The principal theories that have had a huge impact in special education field have a psychological attribute. We are talking about those theories that were on mental impairments centred: the genetic viscosity theory (B. Inhelder); the limited area of future subsequent area of psychological development - L.S.Vâgotski, the development's hetero-chrony - R. Zazzo; the oligophrenia inertia - A.R. Luria. Principles and research's findings of these great titans of the special education field have build researches and a more appropriate education centered on individual characteristics, with theories that try to give explications and possible solution. Constantin Paunescu (1976) through "commutative theory of learning", propose two steps in promoting teaching-learning contents, methods and procedure: a. first the methods accessible to mental development of child; b. following the acquisitions that will be "switched", according to what should be acquire in chronological age, with gradual learning based on higher semantic units. Emil Verza (2006) have fundaments the total communication theory that demonstrate the need to stimulate communication to all categories of children with disabilities by the most varied ways, including altemative language, nonverbal and augmentative. D.V. Popovici (2006) develops the original Zazzo's theory and demonstrate hetero-chrony on gifted pupils.

More researches is increasingly reported toward constructivist paradigm .From the perspective of special education, research gradually turned to social constructivism of Lev Vâgotski which reveal the socio- genetic aspects of human psyche, the model of socio-cultural structures of the training; in special education of mentally retarded children, subsequent area of psychological development can be extend only by specific support for active, constructive learning process and by the quality of adult-pupil interaction as the basis of 
cognitive development. Jerome S. Bruner's theory have conducted research on: the gradual development and strengthening of intellectual operations as tools of thinking; processing information at the action, iconic and verbal levels during the lesson sessions; thinking development by specific design of computer games, etc.

The theory of structural cognitive modifiability is one of the most publicized theories in Romania by major institutions like: the Institute of Educational Sciences; University "Babes-Bolyai" in Cluj-Napoca, which opened in 2010, International Institute for Mediated Learning and Cognitive structural "Reuven Feuerstein" and by Association "Feuerstein - Open your mind, etc. The theory of structural cognitive modifiability (1979) has methodological and pragmatic value for research in special education explained by her particular concepts, programs and tools that she propose: a. define Structural Cognitive Modifiability as "a structural change in individual functioning, reflecting a change in the common way of development; $\mathbf{b}$. illustrates the difference between a common educational experience and expertise to produce structural change $c$. propose the concepts of mediation and mediated leaming experience; Mediated Leaming Experience can be measure by indicators expressing the level of support necessary for the person to "build" their own knowledge by experience, to create models, mental schemes that change through assimilation and accommodation, d. offers a Instrumental Enrichment Programs which manages to get shaping structural intervention, is focused on student's activism e. provide to teachers a important tool for conceptualizing the relationship between characteristics of learning task and performance of the subject, namely Cognitive map ; Cognitive map defines a mental act in terms of seven parameters, which allows to analyze and interpret the subject's performance f. masterly systematizes deficient cognitive functions, but the programs and tools offered promotes positive approach.

The systematic and psychosocial approach of the pupils personality (Mielu Zlate, 1997) is reflected in researches oriented to goal and objectives like: better description of personality - openness to experience, conscientiousness, extraversion and agreeableness of blind teenager; how enabling an impaired person to reach an optimum mental, physical and/or social functional level; measures intended to compensate for a loss of function or a functional limitation; the possibility and importance of development of creativity of sensory impaired pupil. Some authors, based on conceptual analysis of B. Nicolescu see as an important research direction in the field: deepening the passage from pluridisciplinarity to interdisciplinarity and transdisciplinarity. Multidisciplinarity provides an overview of all the problems observed by telescopes of different specialists; interaction between disciplines can lead to defining interdisciplinarity mutual integration concepts, with methodological approach and coordination related actions needed on several levels. Transdisciplinarity (concept invented by Jean Piaget, en) is defined by 
Eftimie Basarab Nicolescu (president and founder of International Center for Transdisciplinary Research and Studies and together with René Berger, of the Study Group on Transdisciplinarity at UNESCO (1992) as "mise en common axiomatic implementation of a range of disciplines". Transdisciplinarity is characterized by Basarab Nicolescu by three methodological postulates: the existence of levels of reality and representation (there are different levels of Reality of the object and, correspondingly, different levels of Reality of the Subject), tertium included logic and complexity. Therefore, the qualities that confer Individuality / personhood, the complexity of factors acting on the child with disabilities, diversity of barriers and even support (medical, psychological, educational, social) that it needs and receives, complexity of personal and interpersonal factors that lead to internalization of extemal influences require trandisciplinarity.

\section{Selected bibliography:}

1. Agence Européenne pour le Développement de l'Education des Personnes ayant des Besoins Particuliers (2003). Les besoins éducatifs particuliers en Europe. Publication thematique Avec la contribution de EURYDICE. Le réseau d'information sur l'éducation en Europe.

2. Bartolo, P. A., Mol Lous, A. and Hofhass, T. (2007) Responding to student diversity: Teacher Education and Classroom Practice. Proceedings of the International Conference on Teacher Education for Responding to Student Diversity.

3. British Journal of Educational Technology.

4. Centre for Disability Studies, University of Leeds, U. K. http://www.leeds.ac.uk/disability-studies!.

5. Chavaroche (2006.). Le projet individuel - Repères pour une pratique avec les personnes gravement handicapées mentales. Ramonville Saint-Agne: Editions Erès, p. 43.

6. Crețu, V., Popovici D. V., Sainsbury, W., Corley, G. (2006). Visually impaired (VI) Education in Romania and the United Kingdom: "Special education in Romania since 1990 for blind and partially sighted children and young people, with comparisons drawn from similar experiences of legislative and educational changes in England and Wales since 1981", Pediatric Rehabilitation.

7. Crețu, V. (2009). Training students and young people with disabilities in relation to their support needs and labour market requirements. Institutions, successful examples, proposals. In I. Neacsu, M. Nica (coord.) Integiarea Socială şi Profesionalä a Tinerilor Dezavantajałi. Bucuresti: Editura Universitara.

8. Cretu V. (coord), Preda, V., Plop, A., Ghioc, S. (2008). Raport de cercetare „Studiu pentru determinarea nevoilor specifice ale utilizatorilor cu 
handicap visual. Institutul Naţional pentru Prevenirea şi Combaterea Excluziunii Sociale a Persoanelor cu Handicap.

9. Darbellay, F., Paulsen, T. (2008). Le défi de l'Inter-et Transdisciplinarité. Concepts, méthodes et pratiques innovantes dans l'enseignement et la recherche. Lausanne: Presses Polytechniques et Universitaires Romandes (PPUR).

10. European Agency for Development in Special Needs Education (2010). Teacher education for Inclusion. Denmark: International Literature Review Odense.

11. Feuerstein, R., Rand, Y., Hoffman, M. (1979). The dynamic assessment of retarded performers: learning potential assessement device, theory, instruments, and techniques. Baltimore: University Park Press.

12. Freeman, St., Marvin, C., Alkin, M. (2000). Academic and Social Attainments of Children with Mental Retardation in General Education and Special Education Settings. In Remedial and Special Education January 2000, vol. 21, no. 1, 3-26.

13. Gallagher, D. J. (2004). The importance of constructivism and constructivist pedagogy for disability studies in education. Disability Studies Quarterly, Spring 2004, 24 (2).

14. Inclusive and Supportive Education Congress (ISEC) August, 2005, Glasgow, Scotland.

15. Kuell, C. (2009). Tapping the creativity of blind and visually impaired students. Dialogue, Vol. 45, No. 2, March-April, 2009.

16. Mackenstadt, D. (2001). The Role of the Paraeducator in the Education of Blind Children. National Organization of Parents of Blind Children Annual Meeting Washington.

17. McHatton, P. A., Daniel, P. L. (2008). Co-Teaching at the Pre-Service Level: Special Education Majors Collaborate with English Education Majors. In Teacher Education and Special Education, 31 (2), 118-131.

18. Nicolescu, B. (2011). The need of transdisciplinarity in High Education. Keynote speaker talk at the International Higher Education Congress "New Trends and Issues", Istanbul, Turkey.

19. Nicolescu, B. (1996). La transdisciplinarité - Manifeste. Monaco: Edition du Rocher, Collection Transdisciplinarité.

20. Practici inclusive pentru adulţii cu deficiențe senzoriale din Europa, „Rezultatele finale ale proiectului Socrates Grundtving”, 2003-2005.

21. Personalized Education Now, newsletter Centre for Personalized Education located Bramcote, England.

22. Popovici D.V., Balota. A. (2007). Introducere in psihopedagogia supradotatilor. București: Edit. Fundatiei Humanitas.

23. Prost, L. (2007). Projet personnalisé et pratique d'accompagnement des personnes polyhandicapées et autistes -Pour une reconnaissance de l'autre 
comme sujet. Dijon: I.R.T.E.S.S. Institut Régional Supérieur du Travail Educatif et Social.

24. Preda, V. (coord) (2009). Universul sistemului Braille in contextul actual al educatiei speciale. Cluj-Napoca: Presa Universitara Clujeana.

25. Reman, J., Beck, L., Marshall, P., Dick, Z., Philip, M, Anita, E. A. (2007). Initial Review of Research Literature on Appropriate Dispute Resolution (ADR) in Special Education. Oregon: Consortium for Appropriate Dispute Resolution in Special Education (CADRE) Eugene.

26. Rink, J. (2005). Teaching physical education for learning. London: McGraw-Hill Ed.

27. Tomlinson, C. (2003). Fulfilling the Promise of the Differentiated Classroom: Strategies and Tools for Responsive Teaching. Alexandria, VA: Association for Supervision and Curriculum Development.

28. Verza, E., Verza, F. (coor.) (2011). Tratat de Psihopedagogie Specială. Bucureşti: Editura Universităţii din Bucureşti.

29. Vicker, B. (2008). Augmentative Communication. Indiana Institute on Disability and Community, BBBAutism Support Network.

30. Vrasmas, E. (2004). Introducere in educatia cerintelor speciale. Bucureşti: Credis. 